\title{
Small Storm Hydrology and Why it is Important for the Design of Stormwater Control Practices
}

Robert Pitt

Different drainage design criteria and receiving water use objectives often require the examination of different types of rains for the design of urban drainage systems. These different (and often conflicting) objectives of a stormwater drainage system can be addressed by using distinct portions of the long-term rainfall record. Several historical examinations (including Heaney, et al. 1977) have also considered the need for the examination of a wide range of rain events for drainage design. However, the lack of efficient computer resources severely restricted long-term analyses in the past. Currently, computer resources are much more available and are capable of much more comprehensive investigations (Gregory and James 1996). In addition to having more efficient computational resources, it is also necessary to re-examine some of the fundamental urban hydrology modeling assumptions (Pitt 1987). Most of the urban hydrology methods currently used for drainage design have been successfully used for large "design" storms. Obviously, this approach (providing urban areas safe from excessive flooding and associated flood related damages) is the most critical objective of urban drainage. However, it is now possible (and legally required in many areas) to provide urban drainage systems that also minimize other problems associated with urban stormwater. This broader set of urban drainage objectives requires a broader approach to drainage design, and the use of hydrologic methods with different assumptions and simplifications.

Pitt, R.E. 1999. "Small Storm Hydrology and Why it is Important for the Design of Stormwater Control Practices." Journal of Water Management Modeling R204-04. doi: 10.14796/JWMM.R204-04.

(C) CHI 1999 www.chijournal.org ISSN: 2292-6062 (Formerly in New Applications in Modeling Urban Water Systems. ISBN: 0-9697422-9-0) 


\subsection{Introduction}

This chapter reviews monitored rainfall and runoff distributions for Milwaukee, WI (data from Bannerman, et al. 1983), and examines long-term rainfall histories and predicted runoff from 24 locations throughout the U.S. The Milwaukee observations show that southeastern Wisconsin rainfall distributions can be divided into the following categories, with possible management approaches relevant for each category of rain:

- Common rains having relatively low pollutant discharges are associated with rains less than about $0.5 \mathrm{in} .(13 \mathrm{~mm})$ in depth. These are key rains when runoff-associated water quality violations, such as for bacteria, are of concern. In most areas, runoff from these rains should be totally captured and either re-used for on-site beneficial uses or infiltrated in upland areas. For most areas, the runoff from these rains can be relatively easily removed from the surface drainage system.

- Rains between 0.5 and 1.5 in. (13 and $38 \mathrm{~mm}$ ) are responsible for about $75 \%$ of the runoff pollutant discharges and are key rains when addressing mass pollutant discharges. The small rains in this category can also be removed from the drainage system and the runoff re-used on site for beneficial uses or infiltrated to replenish the lost groundwater infiltration associated with urbanization. The runoff from the larger rains should be treated to prevent pollutant discharges from entering the receiving waters.

- Rains greater than 1.5 in. $(38 \mathrm{~mm})$ are associated with drainage design and are only responsible for relatively small portions of the annual pollutant discharges. Typical storm drainage design events fall in the upper portion of this category. Extensive pollution control designed for these events would be very costly, especially considering the relatively small portion of the annual runoff associated with the events. However, discharge rate reductions are important to reduce habitat problems in the receiving waters. The infiltration and other treatment controls used to handle the smaller storms in the above categories would have some benefit in reducing pollutant discharges during these larger, rarer storms.

- In addition, extremely large rains also infrequently occur that exceed the capacity of the drainage system and cause local flooding. Two of these extreme events were monitored in Milwaukee during the Nationwide Urban Runoff Program (NURP) project (EPA 1983). These storms, while very destructive, are sufficiently rare that the resulting environmental problems do not justify the massive stormwater quality controls that would be necessary for their reduction. The problem during these events is massive property damage and possible 
loss of life. These rains typically greatly exceed the capacities of the storm drainage systems, causing extensive flooding. It is critical that these excessive flows be conveyed in "secondary" drainage systems. These secondary systems would normally be graded large depressions between buildings that would direct the water away from the buildings and critical transportation routes and to possible infrequent/ temporary detention areas (such as large playing fields or parking lots). Because these events are so rare, institutional memory often fails and development is allowed in areas that are not indicated on conventional flood maps, but would suffer critical flood damage.

Obviously, the critical values defining these rain categories are highly dependent on local rain and development conditions. Computer modeling analyses from several representative urban locations from throughout the U.S. are presented in this chapter. These modeled plots indicate how these rainfall and runoff probability distributions can be used for more effective storm drainage design in the future. In all cases, better integration of stormwater quality and drainage design objectives will require the use of long-term continuous simulations of alternative drainage designs in conjunction with upland and end-of-pipe stormwater quality controls. The complexity of most receiving water quality problems prevents a simple analysis. The use of simple design storms, which was a major breakthrough in effective drainage design more than 100 years ago, is not adequate when receiving water quality issues must also be addressed.

This chapter also reviews typical urban hydrology methods and discusses common problems in their use in predicting flows from these important small and moderate sized storms. A general model is then described, and validation data presented, showing better runoff volume predictions possible for a wide range of rain conditions.

\subsection{Runoff and Pollutant Yields for Different Rain Categories}

Figure 4.1 includes cumulative probability density functions (CDFs) of measured rain and runoff distributions for Milwaukee during the 1981 NURP monitored rain year (data from Bannerman, et al. 1983). CDFs are used for plotting because they clearly show the ranges of rain depths responsible for most of the runoff. Rains between $0.05(.1 \mathrm{~mm})$ and $5 \mathrm{in} .(120 \mathrm{~mm})$ were monitored during this period, with two very large events, greater than $3 \mathrm{in}$. $(77 \mathrm{~mm})$, occurred during this monitoring period which greatly distort these curves, compared to typical rain years. The following observations are evident:

- The median rain depth was about 0.3 in. $(7.7 \mathrm{~mm})$.

- $66 \%$ of all Milwaukee rains are less than 0.5 in. $(13 \mathrm{~mm})$ in depth. 
- For medium density residential areas, $50 \%$ of runoff was associated with rains less than 0.75 in. $(19 \mathrm{~mm})$.

- A 100-yr., 24-hr rain of $5.6 \mathrm{in.}(140 \mathrm{~mm})$ for Milwaukee could produce about $15 \%$ of the typical annual runoff volume, but it only contributes about $0.15 \%$ of the average annual runoff volume, when amortized over 100 yrs.

- Similarly, a 25-yr., 24-hr rain of 4.4 in. (110 mm) for Milwaukee could produce about $12.5 \%$ of the typical annual runoff volume, but it only contributes about $0.5 \%$ of the average annual runoff volume, when amortized over 25 yrs.

Figure 4.2 shows CDFs of measured Milwaukee pollutant loads associated with different rain depths for a medium density residential area. Suspended solids, COD, lead, and phosphate loads are seen to closely follow the runoff volume CDF shown in Figure 4.1, as expected. Since load is the product of concentration and runoff volume, some of the high correlation shown between load and rain depth is obviously spurious. However, these overlays illustrate the range of rains associated with the greatest pollutant discharges.

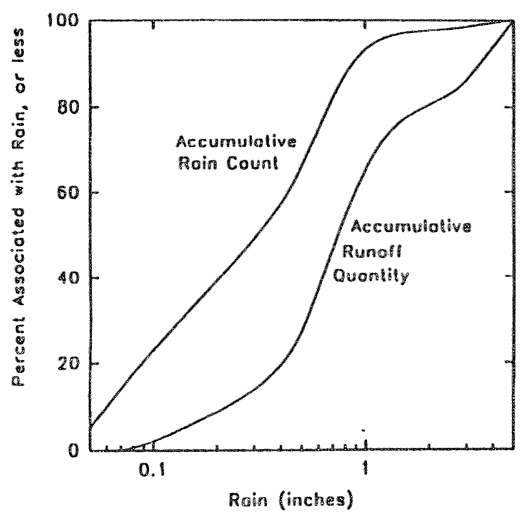

Figure 4.1 Milwaukee rain and runoff cumulative probability density functions (CDFs).

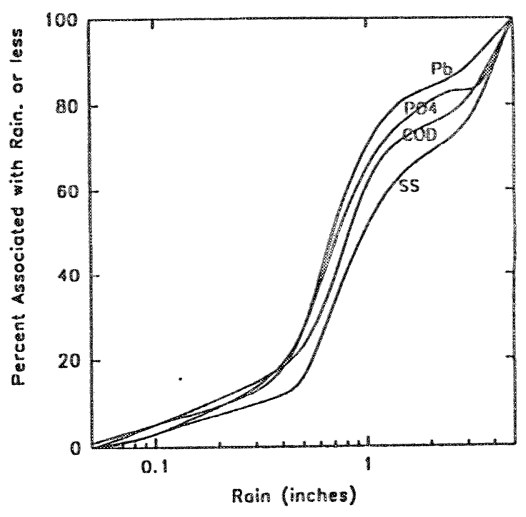

Figure 4.2 Milwaukee stormwater pollutant cumulative probability density functions (CDFs).

The monitored rainfall and runoff distributions for Milwaukee show the following distinct rain categories:

- $<0.5 \mathrm{in} .(13 \mathrm{~mm})$. These rains account for most of the events, but little of the runoff volume, and are therefore easiest to control. They produce much less pollutant mass discharges and probably have less receiving water effects than other rains. However, the runoff pollutant concentrations likely exceed regulatory standards for several 
categories of critical pollutants, especially bacteria and some total recoverable metals. They also cause large numbers of overflow events in uncontrolled combined sewers. These rains are very common, occurring once or twice a week (accounting for about $60 \%$ of the total rainfall events and about $45 \%$ of the total runoff events that occurred), but they only account for about $20 \%$ of the annual runoff and pollutant discharges. Rains less than about 0.05 inches did not produce noticeable runoff.

- $0.5(13 \mathrm{~mm})$ to $1.5 \mathrm{in}$. (38 mm). These rains account for most of the runoff volume (about $50 \%$ of the annual volume for this Milwaukee example) and produce moderate to high flows. They account for about $35 \%$ of the annual rain events, and about $20 \%$ of the annual runoff events. These rains occur on the average about every two weeks during the spring to fall seasons and subject the receiving waters to frequent high pollutant loads and moderate to high flows.

- $1.5(38 \mathrm{~mm})$ to 3 in. $(77 \mathrm{~mm})$. These rains produce the most damaging flows, from a habitat destruction standpoint, and occur every several months (at least once or twice a year). These recurring high flows, which were historically associated with much less frequent rains, establish the energy gradient of the stream and cause unstable streambanks. Only about $2 \%$ of the rains are in this category and they are responsible for about $10 \%$ of the annual runoff and pollutant discharges.

- $>3 \mathrm{in} .(77 \mathrm{~mm})$. This category is rarely represented in field studies due to the rarity of these large events and the typically short duration of most field observations. The smallest rains in this category are included in design storms used for drainage systems in Milwaukee. These rains occur only rarely (once every several years to once every several decades, or less frequently) and produce extremely large flows. The 3-year monitoring period during the Milwaukee NURP program (1980 through 1983) was unusual in that two of these events occurred. Less than $2 \%$ of the rains were in this category (typically $<<1 \%$ would be), and they produced about $15 \%$ of the annual runoff quantity and pollutant discharges. During a "normal" period, these rains would only produce a very small fraction of the annual average discharges. However, when they do occur, great property and receiving water damage results. The receiving water damage (mostly associated with habitat destruction, sediment scouring, and the flushing of organisms great distances downstream and out of the system) can conceivably naturally recover to before-storm conditions within a few years. 
Similar rain categories can be determined for other areas, besides Milwaukee. Long-term continuous simulations were made using SLAMM, the Source Loading and Management Model (Pitt 1986; Pitt and Voorhees 1995) for 24 representative locations from throughout the U.S. These locations represent most of the major river basins and much of the rainfall variations in the country. These analyses are intended to show the importance of smaller rains for many different regions and conditions in the U.S.

These simulations were based on 5 to 10 years of rainfall records, usually containing about 500 individual rains. The rainfall records were from certified NOAA weather stations and were obtained from CD-ROMs distributed by EarthInfo of Boulder, $\mathrm{CO}$. Hourly rainfall depths for the indicated periods were downloaded from the CD-ROMs into an Excel spreadsheet. This file was then read by an utility program included in the SLAMM software package. This rainfall file utility combined adjacent hourly rainfall values into individual rains, based on user selections (at least $6 \mathrm{hrs}$ of no rain was used to separate adjacent rain events and all rain depths were used, with the exception of the "trace" values; similar analyses were made using inter-event definitions ranging from 3 to 24 hours, with little differences in the conclusions.). These rain files for each city were then used in SLAMM for typical medium density and strip commercial developments. The outputs of these computer runs were then plotted as shown on Figures 4.3a through $4.3 \mathrm{c}$.

Table $4.1(\mathrm{a} \& \mathrm{~b})$ summarizes these rain and runoff distributions for different U.S. locations. Lower and upper runoff distribution breakpoints were identified on all of the individual distributions. Ranges are given for many of the values, corresponding to different land use conditions (medium density residential and commercial areas). In most cases, the range covers a relatively narrow set of values. The breakpoints separate the distributions into the following three general categories:

- less than lower breakpoint: small, but frequent rains. These generally account for $50 \%$ to $70 \%$ of all rain events (by number), but only produce about $10 \%$ to $20 \%$ of the runoff volume. The rain depth for this breakpoint ranges from about $0.10 \mathrm{in} .(2.5 \mathrm{~mm})$ in the Southwest arid regions of the U.S., to about $0.5 \mathrm{in} .(13 \mathrm{~mm})$ in the wet Southeast. These events are most important because of their frequencies, not because of their mass discharges. These rains are therefore of great interest where water quality violations associated with urban stormwater occur. This would be most common for fecal coliform bacteria and for total recoverable heavy metals which typically exceed receiving water numeric criteria during practically every rain event in heavily urbanized drainages having separate stormwater drainage systems.

- between the lower and upper breakpoint: moderate rains. These rains generally account for $30 \%$ to $50 \%$ of all rain events (by number), but 

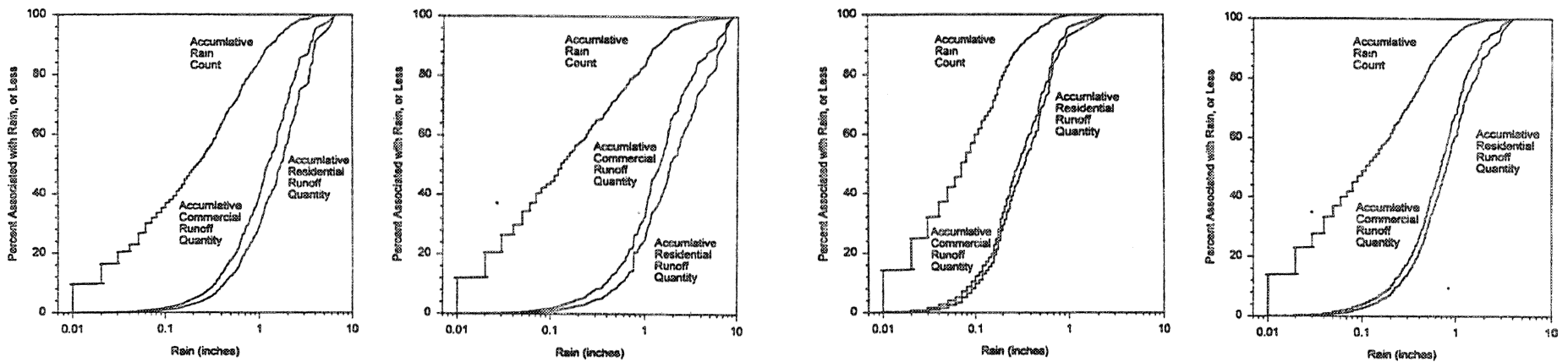

Billings, MT Rain \& Runoff Distributions ('8E.'s3) Bimingham, AL Rain \& Runof Distributions ('81:'89)
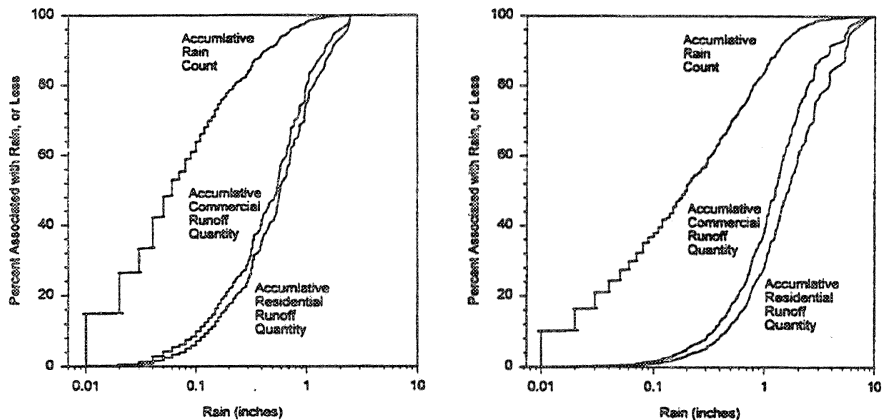

Columbus, OH Rain \& Runof Distributions ['sG-'92)

Donver, CO Rain \& Runom Distributions ('83-'93)
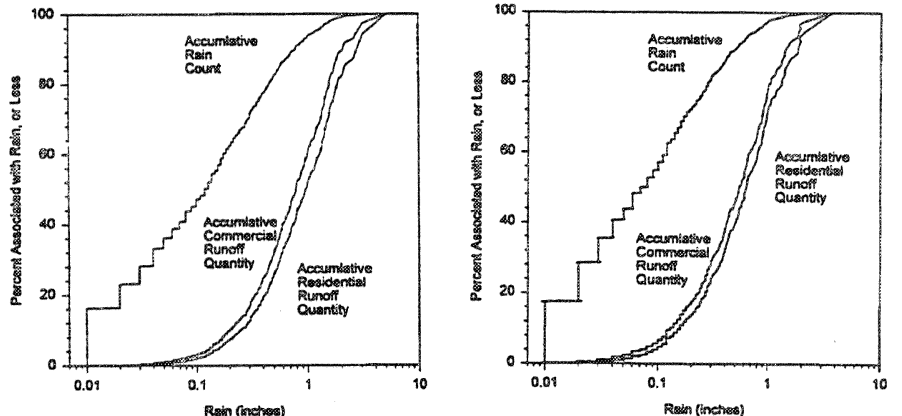

Figure 4.3a Modeled rainfall and runoff cumulative probability density functions (CDFs) (percent associated with rain vs. rain). 
Detroth, an Rasin \& Runoef Distributions ('E6-'92)
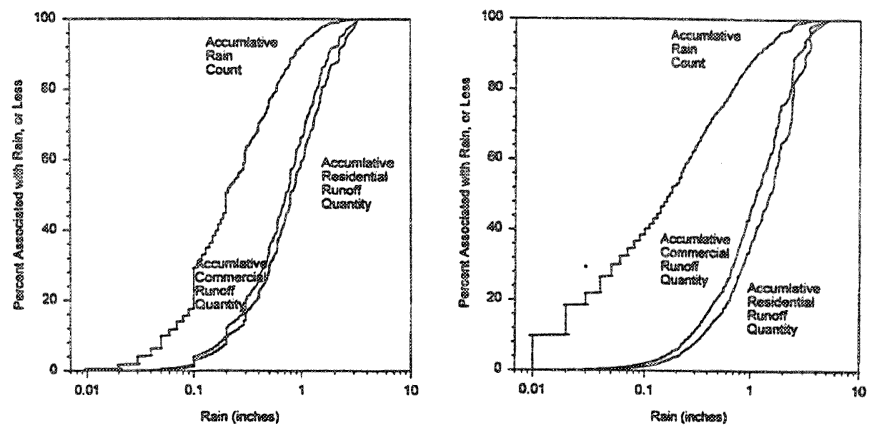

Madison, WI Rain \& Runo: Distributions ('BA'-B)]

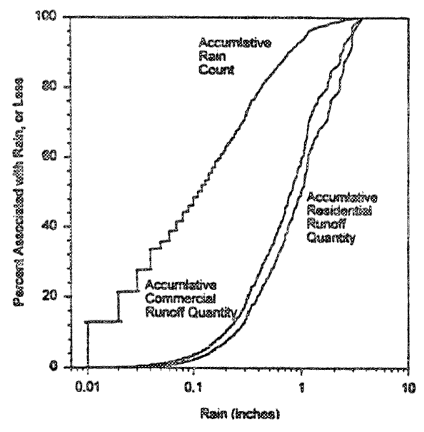

Miami, FL Rain \& Runofr Distributions ('87's2)

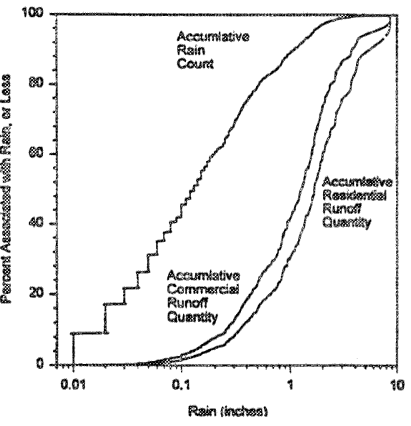

Miwwaukes, W1 Rain \& Runof Distributions ('82-'g8)
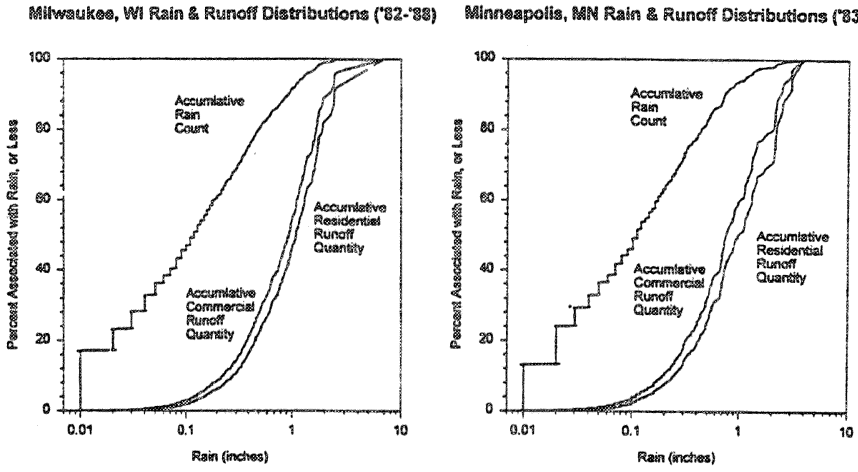

Newark, MJ Rain \& Runoff Digtributions ('82.'32)
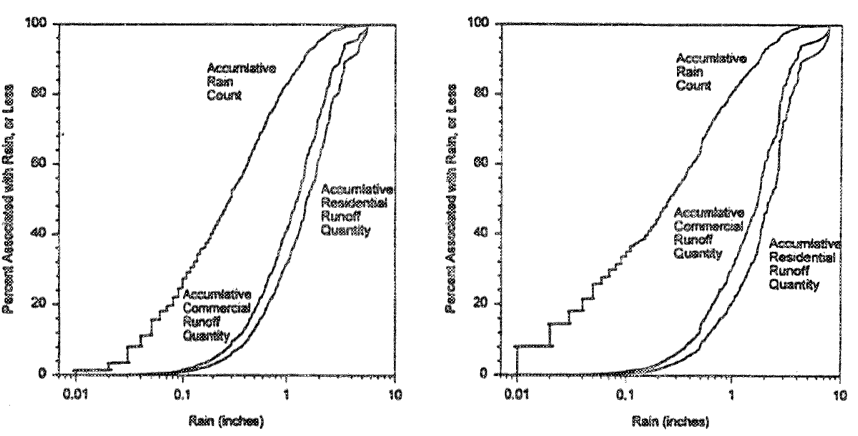

$\infty$

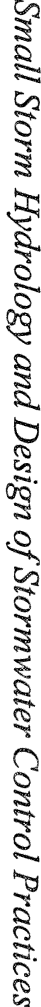

Figure 4.3b Modeled rainfall and runoff cumulative probability density functions ( $\mathrm{CDFs}$ ) (percent associated with rain vs. rain), cont. 


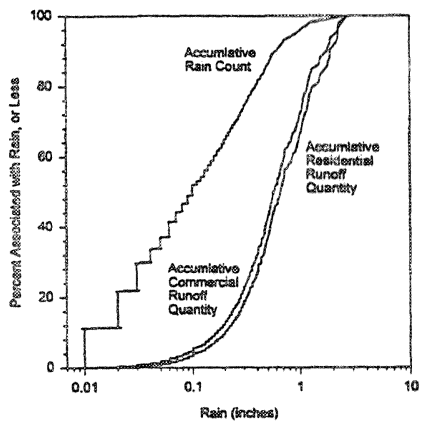

Rabigh, MC Rain \& Runom Distributions ('24-32)

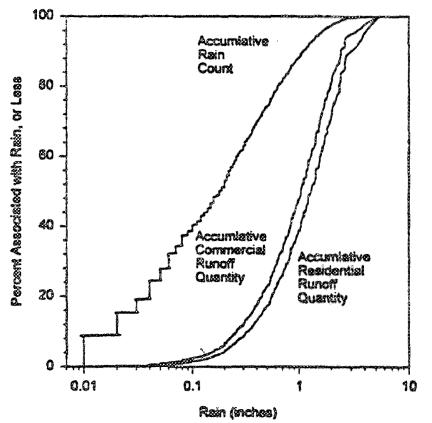

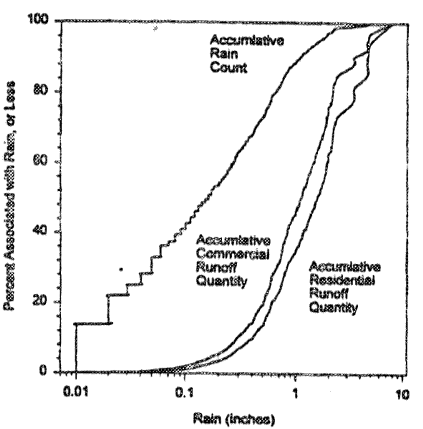

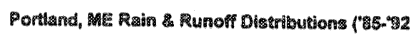

Rapid City, SQ Rain \& Runofi Distributions ('33-'g3

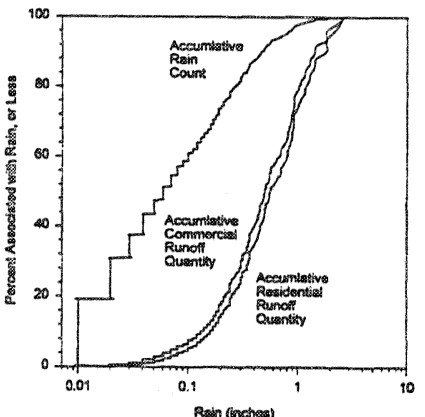

Rిano, NV Rain \& Runoff Distributons (77.'93)

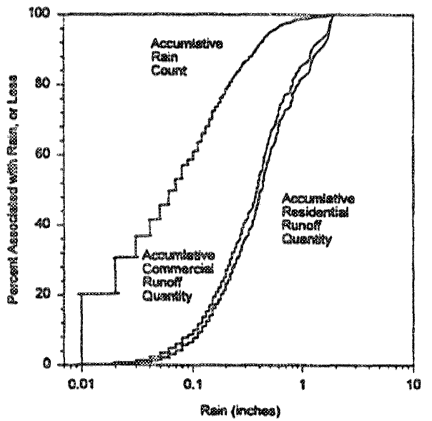

St. Louis, MO Rain \& Runoff Distributions ('24:'92)

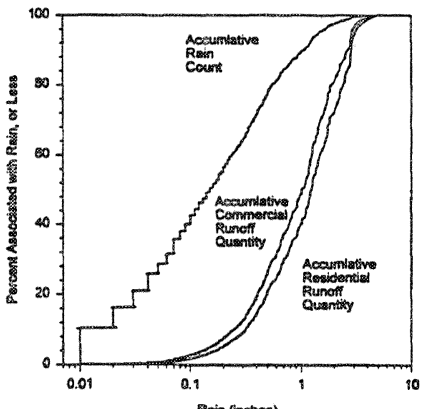

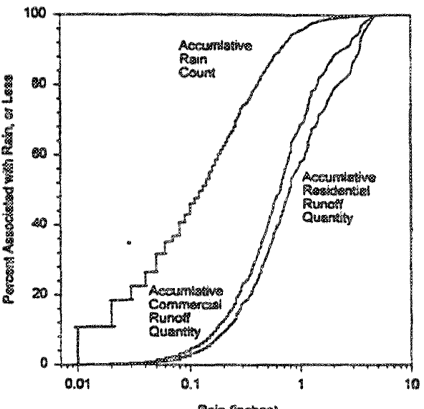

$A$

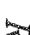

है

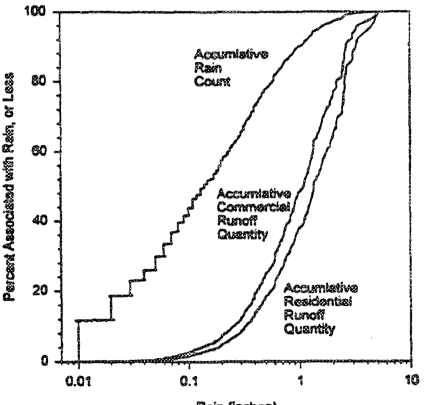

Figure 4.3c Modeled rainfall and runoff cumulative probability density functions (CDFs) (percent associated with rain vs. rain), cont. 
Table 4.1a Rainfall and runoff distribution characteristics for different U.S. locations.

\begin{tabular}{|c|c|c|c|c|c|c|}
\hline & $\begin{array}{l}\text { Median } \\
\text { rain } \\
\text { depth, by } \\
\text { count (in) }\end{array}$ & $\begin{array}{l}\text { Percentage } \\
\text { of runoff } \\
\text { occurring } \\
\text { during rains } \\
\text { less than the } \\
\text { median rain } \\
\text { depth }\end{array}$ & $\begin{array}{l}\text { Rain depth } \\
\text { associated } \\
\text { with median } \\
\text { runoff depth } \\
\text { (in) }\end{array}$ & $\begin{array}{l}\text { Lower } \\
\text { break- } \\
\text { point } \\
\text { rain } \\
\text { depth } \\
\text { (in) }\end{array}$ & $\begin{array}{l}\text { Percentage } \\
\text { of rain } \\
\text { events less } \\
\text { than lower } \\
\text { breakpoint }\end{array}$ & $\begin{array}{l}\text { Percentage } \\
\text { of runoff } \\
\text { volume } \\
\text { less than } \\
\text { lower } \\
\text { breakpoint }\end{array}$ \\
\hline Boise, ID & 0.07 & $3 \cdot 5$ & $0.30 \cdot 0.35$ & 0.10 & 52 & $9 \cdot 11$ \\
\hline Seattle, WA & 0.12 & $4-6$ & $0.62-0.80$ & 0.18 & 60 & $8-11$ \\
\hline Los Angeles, CA & 0.18 & $3-5$ & $1.2-1.5$ & 0.29 & 64 & $7-10$ \\
\hline Reno, NV & 0.07 & $3-5$ & $0.35-0.41$ & 0.10 & 61 & $8 \cdot 10$ \\
\hline Phoenix, AZ & 0.10 & $4 \cdot 6$ & $0.55-0.68$ & 0.19 & 64 & $9-12$ \\
\hline Billings, MT & 0.06 & $2-4$ & $0.55-0.60$ & 0.12 & 64 & $8-10$ \\
\hline Denver, CO & 0.08 & $2-4$ & $0.50-0.60$ & 0.19 & 71 & $13-17$ \\
\hline Rapid City, SD & 0.06 & $2-4$ & $0.50-0.55$ & 0.15 & 69 & $10 \cdot 13$ \\
\hline Wichita, KS & 0.13 & $2-5$ & $1.1-1.4$ & 0.31 & 65 & $10 \cdot 13$ \\
\hline Austin, TX & 0.14 & $2-3$ & $1.4 \cdot 1.8$ & 0.50 & 72 & $8 \cdot 12$ \\
\hline Minneapolis, MN & 0.11 & $3 \cdot 5$ & $0.73 \cdot 1.0$ & 0.22 & 65 & $9-13$ \\
\hline Madison, WI & 0.12 & $3-5$ & $0.78-0.98$ & 0.23 & 65 & $9-13$ \\
\hline Milwaukee, WI & 0.12 & $2-4$ & $0.9-1.1$ & 0.25 & 65 & $9 \cdot 12$ \\
\hline St. Louis, MO & 0.14 & $4-6$ & $1.0-1.2$ & 0.31 & 65 & $10 \cdot 13$ \\
\hline Detroit, MI & 0.20 & $7-11$ & $0.72-0.81$ & 0.20 & 50 & $7-11$ \\
\hline Buffalo, NY & 0.11 & $2-4$ & $0.61-0.72$ & 0.12 & 64 & $8-12$ \\
\hline Columbus, $\mathrm{OH}$ & 0.12 & $3-5$ & $0.80-1.0$ & 0.22 & 63 & $8-12$ \\
\hline Portland, ME & 0.15 & $2-4$ & $1.1-1.5$ & 0.30 & 64 & $8-12$ \\
\hline Newark, NJ & 0.28 & $6-12$ & $1.2-1.5$ & 0.33 & 54 & $8-12$ \\
\hline New Orleans, LA & 0.25 & $3-5$ & $1.7-2.2$ & 0.45 & 62 & $7-11$ \\
\hline Atlanta, GA & 0.22 & $3-5$ & $1.2-1.7$ & 0.32 & 58 & $5-9$ \\
\hline Birmingham, $\mathrm{AL}$ & 0.20 & $3-5$ & $1.2-1.5$ & 0.40 & 64 & $8-13$ \\
\hline Raleigh, NC & 0.18 & $4-6$ & $1.0-1.2$ & 0.26 & 60 & $7-11$ \\
\hline Miami, FL & 0.13 & $3-5$ & $1.2-1.6$ & 0.30 & 67 & $9 \cdot 13$ \\
\hline
\end{tabular}

produce $75 \%$ to $90 \%$ of all of the runoff volume. The rain depths associated with the upper breakpoint range from about 1 to $2 \mathrm{in}$. (26 to $51 \mathrm{~mm}$ ) in the arid parts of the U.S. and up to 5 or 6 in. (130 to 150 $\mathrm{mm}$ ) in wetter areas. As shown earlier for monitored events in Milwaukee and elsewhere, these runoff volume distributions are approximately the same as the pollutant distributions. Therefore, these intermediate rains also account for most of the pollutant mass discharges and much of the receiving water problems associated with stormwater discharges. 
Table 4.1 b Rainfall and runoff distribution characteristics for different U.S. locations.

\begin{tabular}{|c|c|c|c|c|c|}
\hline & $\begin{array}{l}\text { Upper } \\
\text { breakpoint } \\
\text { rain depth } \\
\text { (in) }\end{array}$ & $\begin{array}{l}\text { Percentage } \\
\text { of rain } \\
\text { events less } \\
\text { than upper } \\
\text { breakpoint }\end{array}$ & $\begin{array}{l}\text { Percentage } \\
\text { of runoff } \\
\text { volume } \\
\text { less than } \\
\text { upper } \\
\text { breakpoint }\end{array}$ & $\begin{array}{l}\text { Percentage } \\
\text { of runoff } \\
\text { volume } \\
\text { between } \\
\text { breakpoints }\end{array}$ & $\begin{array}{l}\text { Percentage } \\
\text { of rain } \\
\text { events } \\
\text { between } \\
\text { breakpoints }\end{array}$ \\
\hline Boise, ID & 0.91 & 99 & 89.93 & $80-82$ & 47 \\
\hline Seattle, WA & 3.4 & 99 & $92-96$ & $84-85$ & 39 \\
\hline Los Angeles, CA & 3.5 & 99 & $92-98$ & $85-88$ & 35 \\
\hline Reno, NV & 1.7 & 99 & $93-95$ & 85 & 38 \\
\hline Phoenix, AZ & 2.3 & 99 & $94-98$ & $85-87$ & 35 \\
\hline Billings, MT & 1.6 & 99 & $89-93$ & $81-83$ & 35 \\
\hline Denver, CO & 1.8 & 99 & $91-95$ & 78 & 28 \\
\hline Rapid City, SD & 1.9 & 99 & $92-96$ & $82-83$ & 30 \\
\hline Wichita, KS & 3.0 & 99 & $88-93$ & $78-80$ & 34 \\
\hline Austin, TX & 6.0 & 99 & $88-94$ & $80-82$ & 27 \\
\hline Minneapolis, MN & 2.8 & 99 & $94-96$ & $83-85$ & 34 \\
\hline Madison, WI & 3.5 & 99 & $97-99$ & $86-88$ & 34 \\
\hline Milwaukee, WI & 2.5 & 99 & $89-95$ & $80-83$ & 34 \\
\hline St. Louis, MO & 2.8 & 99 & $90-95$ & $80-82$ & 34 \\
\hline Detroit, MI & 2.4 & 99 & $92-95$ & $85-84$ & 49 \\
\hline Buffalo, NY & 2.1 & 99 & $88-93$ & $80-81$ & 35 \\
\hline Columbus, $\mathrm{OH}$ & 2.2 & 99 & $85-91$ & $77-79$ & 36 \\
\hline Portland, ME & 4.5 & 99 & $90-96$ & $82-84$ & 35 \\
\hline Newark, NJ & 3.3 & 99 & $89-94$ & $81-82$ & 45 \\
\hline New Orleans, LA & 4.0 & 99 & $88-93$ & $81-82$ & 37 \\
\hline Atlanta, GA & 4.0 & 99 & $91-95$ & 86 & 41 \\
\hline Birmingham, AL & 5.0 & 99 & $90-96$ & $82-83$ & 35 \\
\hline Raleigh, NC & 2.5 & 99 & $87-93$ & $80-82$ & 39 \\
\hline Miami, FL & 4.0 & 99 & $87-93$ & $78-80$ & 32 \\
\hline
\end{tabular}

- above the upper breakpoint: large, but rare rains. These rains include the typical drainage design events and are therefore quite rare. During the period analyzed, many of the sites only had one or two, if any, events above this breakpoint. These rare events can account for about $5 \%$ to $10 \%$ of the runoff in years when they occur. Obviously, these events must be evaluated to ensure adequate drainage capacity.

Because of the importance of small and moderate rains, it is important to review conventional urban hydrology methods commonly used to calculate runoff from urban areas. These tools have been reasonably successful when 
evaluating drainage capacity for large "design storm" events. However, the following paragraphs will indicate their short-comings when used for evaluating the common smaller events. A general urban runoff model is also presented that has been shown to be useful to calculate runoff volumes for a wide range of rain events, especially the small and moderate rains of greatest interest in water quality evaluations.

\subsection{Observed Runoff Volumes do not Compare Well with Conventional Urban Runoff Methods}

One of the most commonly-used stormwater design methods utilizes the Natural Resources Conservation Service (NRCS) curve number $(\mathrm{CN})$ method as used in TR-20 and TR-55 (SCS 1986). The NRCS recommends against the use of the curve number procedure for rains less than one-half inch. Unfortunately, this warning is ignored in many urban runoff models that have been developed. As shown previously, small rains are very significant when analyzing urban runoff. In addition, the NRCS recommends that the curve number method should be used for individual components of the drainage area, if $\mathrm{CN}$ values differ by more than 5 , instead of using a composite $\mathrm{CN}$ for the complete area. Unfortunately, many users of the $\mathrm{CN}$ method ignore these two basic warnings, and many urban stormwater models use composite $\mathrm{CN}$ values for all storms. The $\mathrm{CN}$ method is a suitable tool if properly used, but unfortunately, it is frequently used for small storms and for water quality evaluations, well beyond its intended use addressing drainage design for conveyance objectives for large rains.

An example of typical errors associated with the misuse of the $\mathrm{CN}$ method is illustrated using commonly-available rainfall and runoff data. Observed $\mathrm{CN}$ (from monitored rain and runoff events) versus rain depth plots were prepared by Pitt, et al. (1997) for: 2 locations in Broward County, FL; 1 site in Dade County, FL; 2 sites in Salt Lake City, UT; and 2 sites in Seattle, WA (from the rainfall-runoff-quality database, Huber 1981), plus 4 sites in Champaign, IL; 5 sites in Irondequoit Bay, NY; 2 sites in Austin, TX; and 1 site in Rapid City, SD (from the NURP data, EPA 1983). All of the test watersheds are typical for these land uses and do not contain any unusual drainage designs or stormwater controls. Figure 4.4 contains plots for medium density residential areas and mixed common urban areas, while Figure 4.5 contains plots for high density and commercial areas.

In all cases, the general pattern is the same: observed curve numbers are all very high for small rains, tapering off as the rains become large. The NRCS CN procedure assumes that the curve numbers are constant for all rains greater than 0.5 inch $(13 \mathrm{~mm})$. However, it may be best to only use the $\mathrm{CN}$ method for rains greater than several inches in depth, in the range of drainage design for 

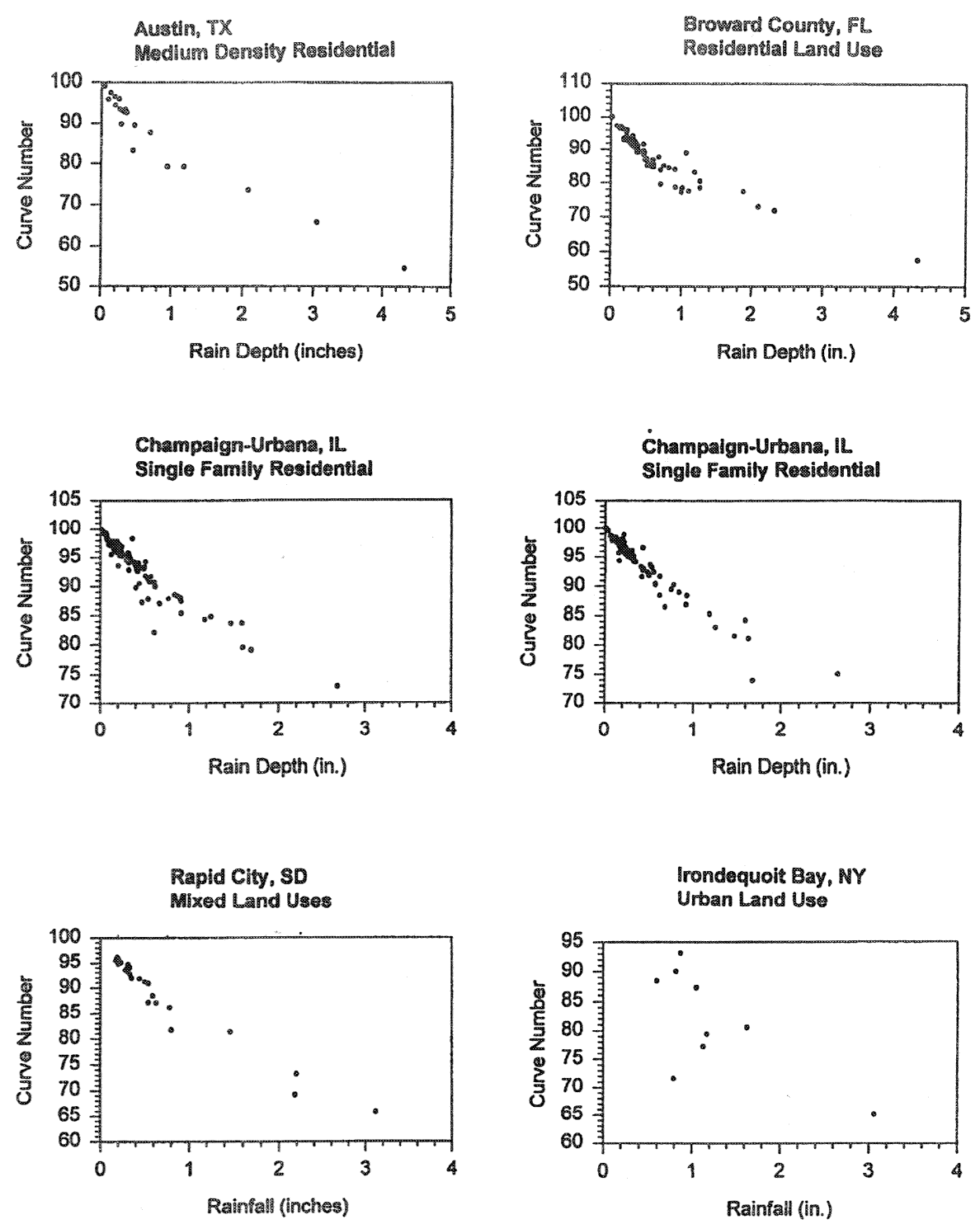

Figure 4.4 Medium density land use area observed $\mathrm{CN}$ vs. rain depth plots.

conveyance, the purpose of the $\mathrm{CN}$ method when it was developed. The reason for the behavior of these plots is based on the simplifications inherent in the $\mathrm{CN}$ method, especially the assumption that initial abstractions are always equal to $20 \%$ of the total abstractions. This assumption may be valid for large rains, resulting in relatively small errors, but the associated errors during small rains become very large. 

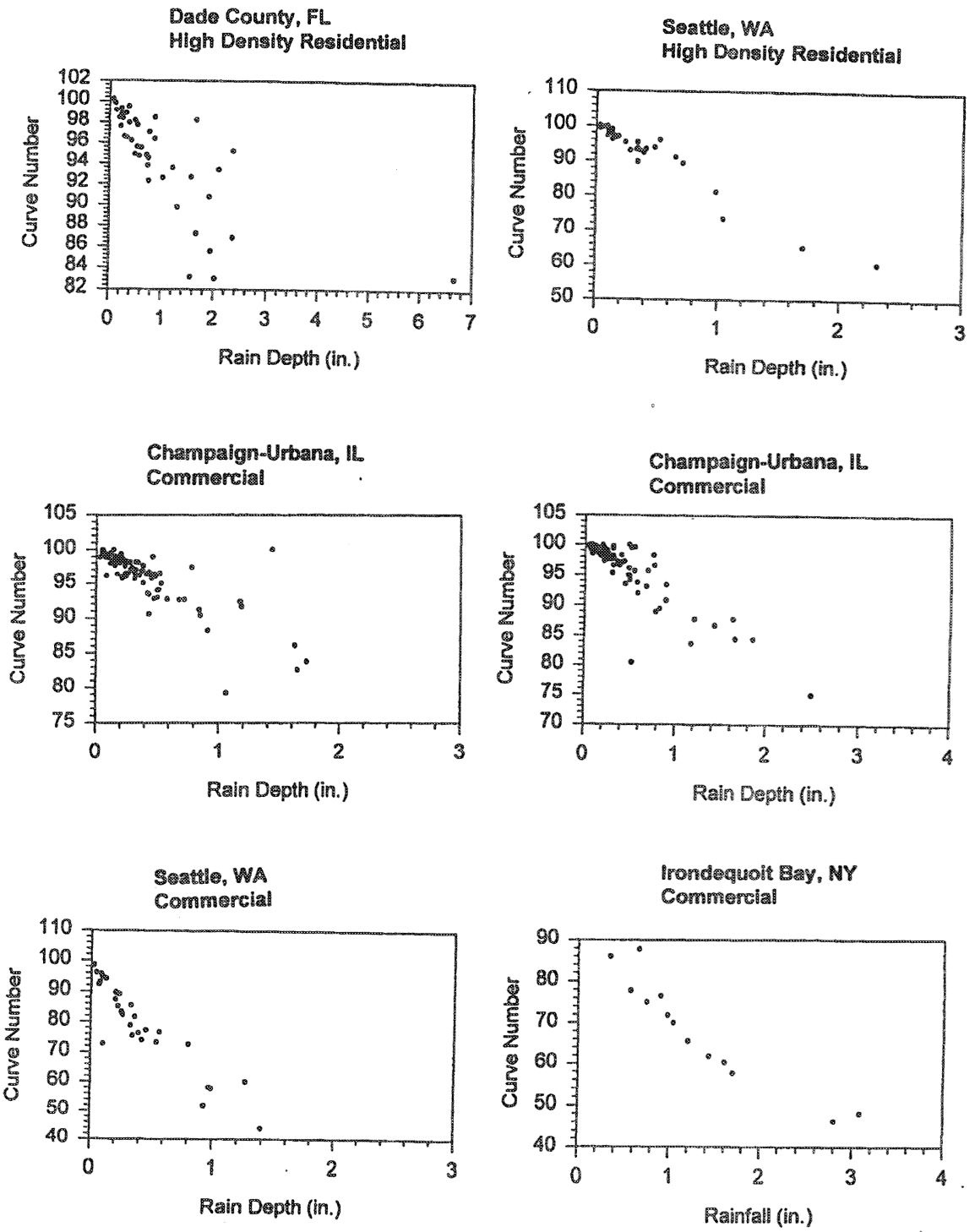

Figure 4.5 High density and commercial land use area observed CN vs. rain depth.

Table 4.2 is a summary of these observed curve numbers at several different rain depths, compared to typical curve numbers presented by the NRCS (SCS 1986) for these land uses. Several of the sites had adequate descriptions to enable curve numbers to be estimated, based on their directly-connected impervious areas and soil texture. The following list shows these sites, with the NRCS recommended curve numbers, and the approximate rain depth where these curve numbers were observed: 
Table 4.2a Observed curve numbers during rainfall-runoff monitoring.

\begin{tabular}{|c|c|c|c|c|c|c|}
\hline Land Use and Location & Directly connected imperviousness & 0.2 in. rain & 0.5 in. rain & 1 in. rain & 3 in. rain & For max. rain observed \\
\hline \multicolumn{7}{|l|}{ Low Density/Suburban } \\
\hline Austin, $\mathrm{TX}$ & $21 \%$ & 94 & 84 & 72 & 53 & $42(5$ in. $)$ \\
\hline Irondequoit Bay, NY & $R v=0.1$ & 95 & 88 & 76 & 55 & $52(4 \mathrm{in})$. \\
\hline Irondequoit Bay, NY & $R v=0.2$ & 94 & 86 & 77 & 57 & $52(4$ in. $)$ \\
\hline Irondequoit Bay, NY & $R v=0.2$ & 94 & 89 & 84 & 69 & $67(4 \mathrm{in.})$ \\
\hline \multicolumn{7}{|l|}{ Medium Density Residential } \\
\hline Austin, TX & $39 \%$ & 96 & 89 & 82 & 66 & $52(5 \mathrm{in})$. \\
\hline Broward County, $\mathrm{FL}$ & $40 \%$ (sandy soils) & 96 & 89 & 81 & 65 & $54(5 \mathrm{in})$. \\
\hline Champaign-Urbana, $\mathbb{L}$ & $18 \%$ (silty, poorly drained soils) & 96 & 94 & 87 & 72 & 71 (4 in.) \\
\hline Champaign-Urbana, IL & $19 \%$ (silty, poorly drained soils) & 98 & 93 & 86 & 74 & $72(4$ in.) \\
\hline Rapid City, SD & mixed & 95 & 92 & 84 & 67 & $63(4 \mathrm{in})$. \\
\hline \multicolumn{7}{|l|}{ High Density Residential } \\
\hline Dade County, FL & "Almost all imperv." (D soils) & 99 & 97 & 94 & 87 & $82(7 \mathrm{in.})$ \\
\hline Seattle, WA & $?$ & 94 & 89 & 80 & $56(\max )$. & \\
\hline \multicolumn{7}{|l|}{ Commercial } \\
\hline Champaign-Urbana & $40 \%$ (silty, poorly drained soils) & 97 & 95 & 89 & $81(\max )$. & \\
\hline Champaign-Urbana & $55 \%$ (sily, poorly drained soils) & 99 & 95 & 89 & $\cdot 74$ & 73 (4 in.) \\
\hline Seattle, WA & $?$ & 90 & 76 & 61 & $44(\max )$. & \\
\hline Irondequoit Bay, NY & $?$ & 92 & 82 & 72 & 46 & $46(4 \mathrm{in})$. \\
\hline \multicolumn{7}{|l|}{ Transportation } \\
\hline Broward County, $\mathrm{FL}$ & $54 \%$ (sandy soils) & 96 & 93 & 86 & 62 & $53(5$ in. $)$ \\
\hline Salt Lake City, UT & Mostly paved (sandy loam) & 91 & 81 & 67 & na & na \\
\hline Salt Lake City, UT & "imperv, roads" (clay loam) & 95 & 84 & 73 & na & na \\
\hline
\end{tabular}


Table 4.2b Typically used curve number values.

\begin{tabular}{|c|c|c|c|c|}
\hline \multirow[t]{2}{*}{ Land Use and Location } & \multicolumn{4}{|c|}{$\begin{array}{l}\text { Estimated CN from NRCS tables for different soil } \\
\text { conditions (if possible, most likely CN highlighted, } \\
\text { based on available site description): }\end{array}$} \\
\hline & $\begin{array}{l}\text { A (sandy to } \\
\text { sandy loam) }\end{array}$ & $\begin{array}{l}\text { B (silt loam } \\
\text { or loam) }\end{array}$ & $\begin{array}{l}\mathrm{C} \text { (sandy clay } \\
\text { loam) }\end{array}$ & $\begin{array}{l}D \text { (silty to } \\
\text { clayey) }\end{array}$ \\
\hline \multicolumn{5}{|l|}{ Low Density/Suburban } \\
\hline Austin, TX & 51 & 68 & 79 & 84 \\
\hline Irondequoit Bay, NY & 46 & 65 & 77 & 82 \\
\hline Irondequoit Bay, NY & 51 & 68 & 79 & 84 \\
\hline Irondequoit Bay, NY & 51 & 68 & 79 & 84 \\
\hline \multicolumn{5}{|c|}{ Medium Density Residential } \\
\hline Austin, TX & 61 & 75 & 83 & 87 \\
\hline Broward County, FL & 61 & 75 & 83 & 87 \\
\hline Champaign-Urbana, IL & 51 & 68 & 79 & 84 \\
\hline Champaign-Urbana, IL & 51 & 68 & 79 & 84 \\
\hline Rapid City, SD & $?$ & $?$ & $?$ & $?$ \\
\hline \multicolumn{5}{|l|}{ High Density Residential } \\
\hline Dade County, FL & 77 & 85 & 90 & 92 \\
\hline Seattle, WA & 77 & 85 & 90 & 92 \\
\hline \multicolumn{5}{|l|}{ Commercial } \\
\hline Champaign-Urbana & 61 & 75 & 83 & 87 \\
\hline Champaign-Urbana & 73 & 82 & 88 & 91 \\
\hline Seattle, WA & $?$ & $?$ & $?$ & $?$ \\
\hline Irondequoit Bay, NY & $?$ & $?$ & $?$ & $?$ \\
\hline \multicolumn{5}{|l|}{ Transportation } \\
\hline Broward County, FL & 73 & 82 & 88 & 91 \\
\hline Salt Lake City, UT & 89 & 92 & 94 & 95 \\
\hline Salt Lake City, UT & 89 & 92 & 94 & 95 \\
\hline
\end{tabular}

- Broward Co., FL, residential land use (40\% imperv., with sandy soils). NRCS CN $=61$, observed at about $3.5 \mathrm{in}$. (90 mm) of rain.

- Champaign-Urbana, IL, single family residential land use (18\% imperv., with silty, poorly drained soils). $\mathrm{NRCS} \mathrm{CN}=84$, observed at about $1.2 \mathrm{in.}(31 \mathrm{~mm})$ of rain.

- Champaign-Urbana, IL, single family residential land use (19\% imperv., with silty, poorly drained soils). NRCS $\mathrm{CN}=84$, observed at about $1.2 \mathrm{in} .(31 \mathrm{~mm})$ of rain. 
- Dade Co., FL, high density residential land use (almostall impervious, "D" soils). NRCS CN =92, observed at about $1.3 \mathrm{in}$. (33 mm) of rain.

- Champaign-Urbana, IL, commercial land use (40\% imperv., with silty and poorly drained soils). NRCS $\mathrm{CN}=87$, observed at about 1.1 in. $(28 \mathrm{~mm})$ of rain.

- Champaign-Urbana, IL, commercial land use (55\% imperv., with silty and poorly drained soils). NRCS CN $=91$, observed at about 0.8 in. $(21 \mathrm{~mm})$ of rain.

- Broward Co., FL, transportation catchment (54\% imperv., with sandy soils). NRCS $\mathrm{CN}=73$, observed at about $1.7 \mathrm{in}$. $(44 \mathrm{~mm})$ of rain.

- Salt Lake City, UT, roadway land use (mostly paved, sandy loam). NRCS CN $=89$, observed at about $0.3 \mathrm{in}$. (8 $\mathrm{mm}$ ) of rain.

- Salt Lake City, UT, transportation catchment (imperv. roads, clay loam). NRCS CN $=95$, observed at about 0.15 in. $(4 \mathrm{~mm}$ ) of rain.

For the rains less than the matching point (rain depth where the NRCS recommended $\mathrm{CN}$ was observed), the $\mathrm{CN}$ is larger than the recommended $\mathrm{CN}$ and the predicted runoff using the NRCS methods would be less than actually occurred. Similarly, for rains larger than the matching point, the $\mathrm{CN}$ is smaller than the recommended $\mathrm{CN}$ and the predicted runoff using the NRCS CN method would be greater than actually occurred. The magnitude of the runoff differences varies greatly, depending on $\mathrm{CN}$ and the rain depth. As an example, if the recommended NRCS CN was 84 , but the $\mathrm{CN}$ was really 98 for a 0.2 in. ( $5 \mathrm{~mm}$ ) rain (similar to the Champaign, IL, medium density residential sites), the percentage error is infinite. For a $1 \mathrm{in} .(26 \mathrm{~mm})$ rain, the $\mathrm{CN}$ at this site was about 86 and the recommended NRCS remains at 84 . The difference now is much smaller, as the rain depth being examined is close to the matching point depth of 1.2 inches $(31 \mathrm{~mm})$. If the rain depth of concern was much larger, say 3 inches $(77 \mathrm{~mm})$, the errors would be in the other direction, as summarized below:

\begin{tabular}{llll}
\hline & $\begin{array}{l}0.2 \text { in. rain (matching } \\
\text { point of } 1.2 \mathrm{in})\end{array}$ & $\begin{array}{l}\text { 1 in. rain (matching } \\
\text { point of } 1.2 \mathrm{in})\end{array}$ & $\begin{array}{l}3 \text { in. rain (matching } \\
\text { point of } 1.2 \mathrm{in})\end{array}$ \\
\hline $\begin{array}{l}\text { Predicted runoff } \\
\text { using CN of } 84 \\
\text { (recommended by }\end{array}$ & $\begin{array}{l}\text { 0 in. of runoff } \\
\text { predicted by NRCS } \\
\text { method }\end{array}$ & $\begin{array}{l}0.15 \text { in. of runoff } \\
\text { predicted by NRCS } \\
\text { method }\end{array}$ & $\begin{array}{l}1.52 \text { in. of runoff } \\
\text { predicted by NRCS } \\
\text { method }\end{array}$ \\
$\begin{array}{l}\text { Actual runoff and } \\
\text { calculated CN }\end{array}$ & $\begin{array}{l}0.10 \text { in. of runoff } \\
\text { observed (actual CN } \\
\text { of } 98)\end{array}$ & $\begin{array}{l}0.20 \text { in. of runoff } \\
\text { observed (actual CN of }\end{array}$ & $\begin{array}{l}0.91 \text { in. of runoff } \\
\text { observed (actual CN } \\
\text { of } 74)\end{array}$ \\
Errors & $\begin{array}{l}\text { Actual runoff is } \\
\text { infinitely larger, } \\
\text { predicted runoff is } \\
\text { infinitely less. }\end{array}$ & $\begin{array}{l}\text { Actual runoff is larger, } \\
\text { predicted runoff is } \\
\text { less. Error of } 25 \% .\end{array}$ & $\begin{array}{l}\text { Actual runoff is less, } \\
\text { predicted runoff is } \\
\text { larger. Error of }-67 \% .\end{array}$ \\
\hline
\end{tabular}


The overall annual runoff depth error associated with using the NRCS recommended $\mathrm{CN}$ method depends on the frequency of rains having the different errors. Because the matching point rainfall depths are close to the rain depth associated with the median runoff depth, the annual errors may be within reason. However, the errors associated with individual events, and for the different categories of rains described earlier, are likely very large. This is a significant problem with stormwater quality management where accurate representations of the sources of the runoff are needed in order to evaluate control practices and development options. If the relative sources of the runoff flows are in great error, inappropriate and wasteful expenditures are likely. It is very obvious that the curve number method should not be used for the small events, as warned by NRCS, but only for the larger "drainage design" classes of storms for which the method was intended.

\subsection{General Urban Hydrology Model}

\subsubsection{Runoff Process for Paved Surfaces}

Initial abstractions are dependent on pavement texture and slope, while infiltration is dependent on pavement porosity and pavement cracks. Typical urban street pavements are relatively porous, in contrast to the much thicker and denser pavements used for freeways and airport runways which are much more impervious. It is the pavement base course that is much more resistant to percolation for urban streets. Infiltrated water is therefore forced to flow laterally towards the pavement edges. If the flow path is long (such as for large parking areas), then the resulting infiltration is limited. Figure 4.6 is an example from a typical pavement runoff test (Pitt 1987). This plot is similar to the SCS plot of rainfall vs. runoff, except it does not have the Ia/S ratio assumption of 0.2 (it is 0.13 in this plot), or other restraints on the curvature of the plot. This and other tests showed that initial abstractions may be about $1 \mathrm{~mm}$ for pavement, while the total infiltration may be between 5 and $10 \mathrm{~mm}$. The maximum losses may occur after about $20 \mathrm{~mm}$ of rain. These abstractions are not very important for large drainage events, where simplifications are appropriate. However, they are very important for small storms, especially in their pattern of variability.

Figure 4.7 a shows that high infiltration rates are associated with high rainfall intensities. The Horton equation assumes a single infiltration relationship as a function of time, irrespective of rain intensity. When variable runoff losses (infiltration losses) are plotted against total rain depth (Figure 4.7b) a single relationship is seen (rain intensity multiplied by time duration gives rain depth). Horton actually recommended infiltration as a function of rain depth, but current practice of using double-ring infiltrometers to calibrate the Horton equation does 


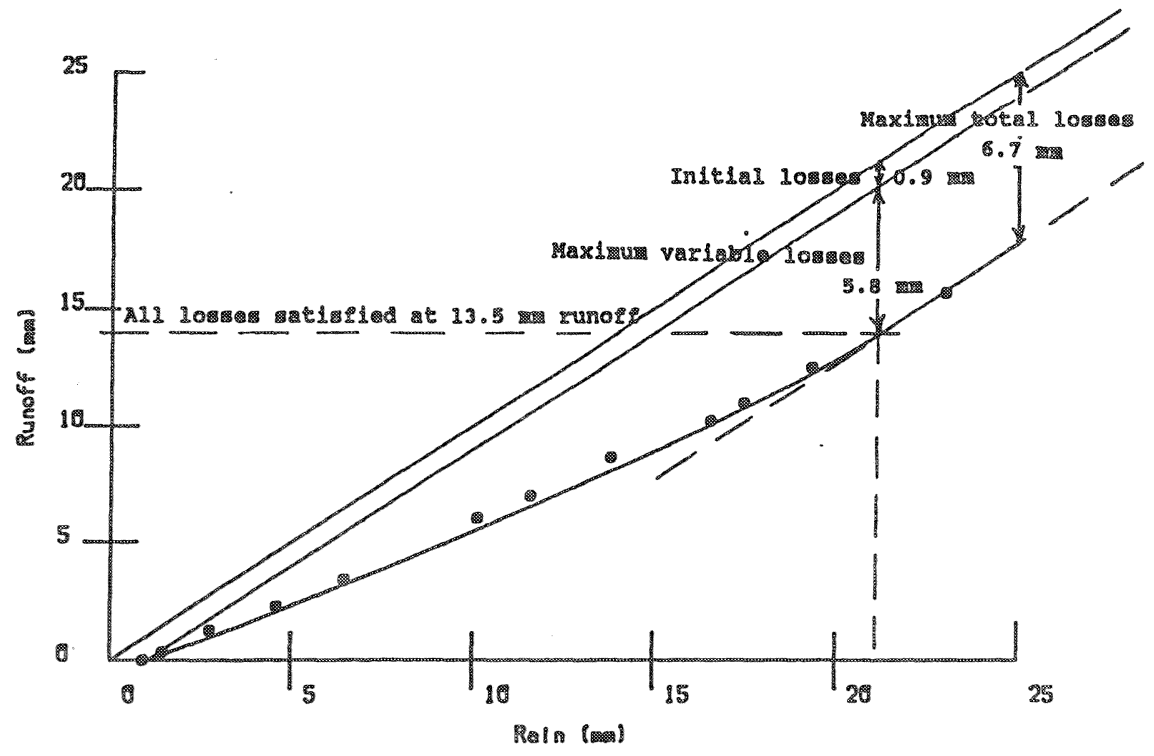

Figure 4.6 Example pavement rainfall-runoff test plot (Pitt 1987).

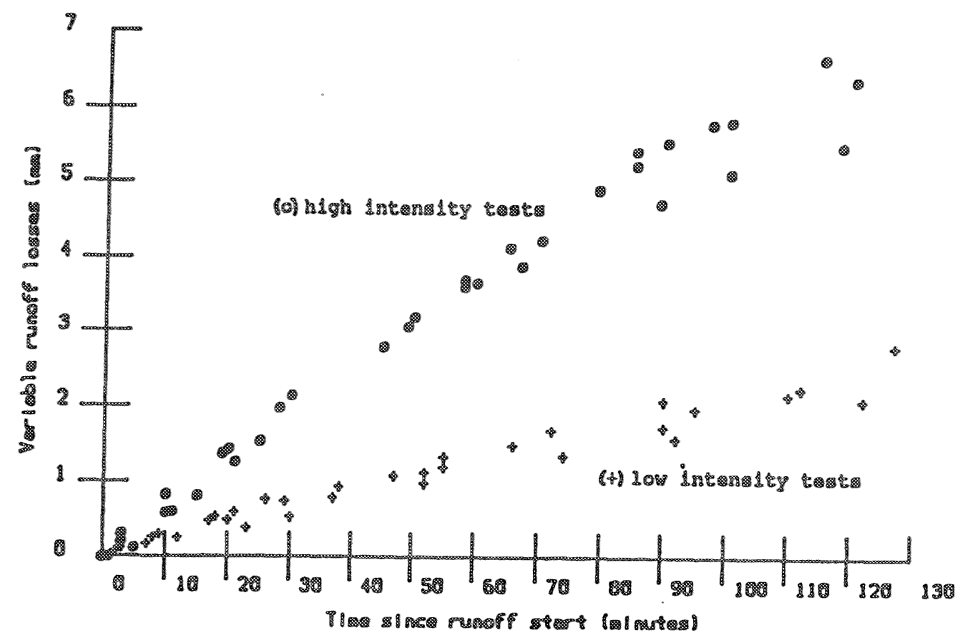

Figure 4.7a Pavement infiltration rates for time since start of rain (Pitt 1987). 


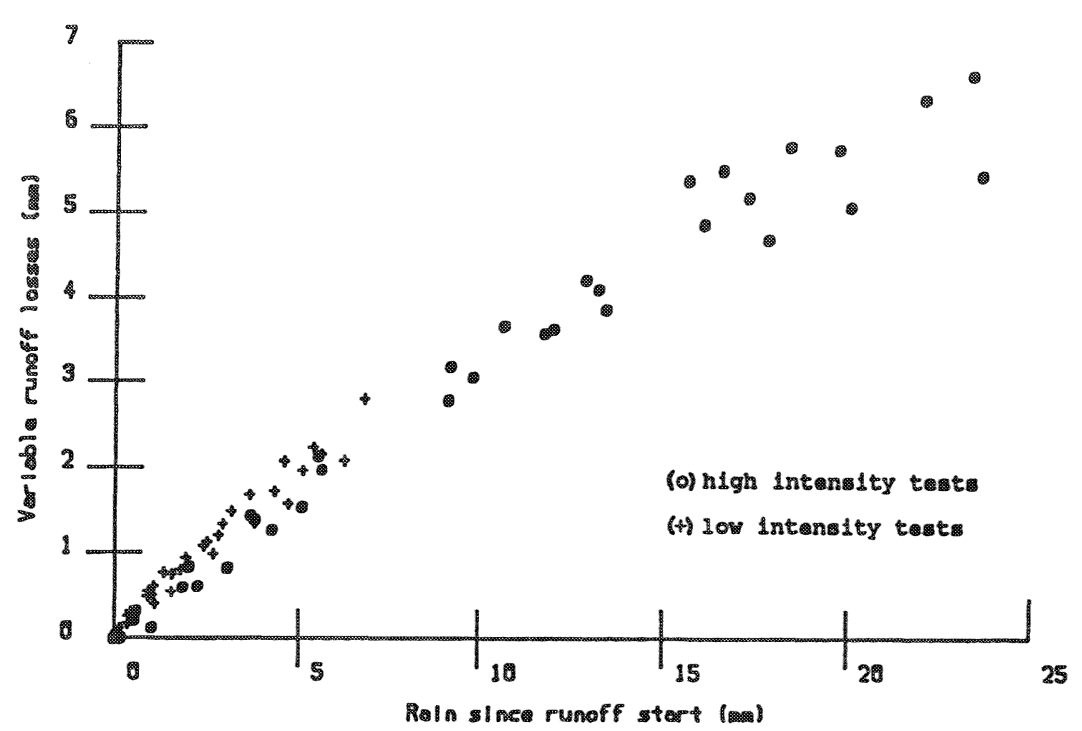

Figure 4.7b Pavement infiltration rates for rain depth since start of rain (Pitt 1987).

not allow infiltration measurements to be made as a function of rain depth, only as a function of time for the ponded test conditions. SWMM uses an integrated Horton equation where infiltration capacity is a function of cumulative infiltration depth, not time.

\subsubsection{Infiltration in Disturbed Urban Soils}

Disturbed urban soils do not behave as indicated by typical models. More rain infiltrates through pavement surfaces and less rain infiltrates through soils than typically assumed. Double-ring infiltrometer test results from Oconomowoc, WI, urban soils (Table 4.3) indicated highly variable infiltration rates for soils that were generally sandy (NRCS A/B hydrologic group soils). The median initial rate was about $3 \mathrm{in} / \mathrm{hr}(77 \mathrm{~mm} / \mathrm{hr})$, but ranged from 0 to $25 \mathrm{in} / \mathrm{hr}(640 \mathrm{~mm} / \mathrm{hr})$. The final rates also had a median value of about $3 \mathrm{in} / \mathrm{hr}(77 \mathrm{~mm} / \mathrm{hr})$ after at least two hours of testing, but ranged from 0 to $15 \mathrm{in} / \mathrm{hr}(380 \mathrm{~mm} / \mathrm{hr})$. Many infiltration rates actually increased with time during these tests. In about $1 / 3$ of the cases, the observed infiltration rates remained very close to zero, even for these sandy soils. Areas that experienced substantial disturbances or traffic (such as school playing fields) had the lowest infiltration rates, typically even lower than concrete or asphalt! These values indicate the large variability in infiltration rates that may occur in areas having supposedly similar soils. Obviously, these variations can significantly affect site specific runoff predictions. The lowest infiltration rates were observed in areas having heavy foot traffic and in areas obviously impacted by silt, while the highest rates were in relatively undisturbed areas. 
Table 4.3 Ranked Oconomowoc, WI, double ring infiltration test results.

\begin{tabular}{|c|c|c|}
\hline \multirow[b]{2}{*}{ Initial Rate } & \multicolumn{2}{|c|}{ Observed urban soil Infiltration rates (in/hr): } \\
\hline & Final Rate (after 2 hours) & Total Observed Rate Range \\
\hline 25 & 15 & 11 to 25 \\
\hline 22 & 17 & 17 to 24 \\
\hline 14.7 & 9.4 & 9.4 to 17 \\
\hline 5.8 & 9.4 & 0.2 to 9.4 \\
\hline 5.7 & 9.4 & 5.1 to 9.6 \\
\hline 4.7 & 3.6 & 3.1 to 6.3 \\
\hline 4.1 & 6.8 & 2.9 to 6.8 \\
\hline 3.1 & 3.3 & 2.4 to 3.8 \\
\hline 2.6 & 2.5 & 1.6 to 2.6 \\
\hline 0.3 & 0.1 & $<0.1$ to 0.3 \\
\hline 0.3 & 1.7 & 0.3 to 3.2 \\
\hline 0.2 & $<0.1$ & $<0.1$ to 0.2 \\
\hline$<0.1$ & 0.6 & $<0.1$ to 0.6 \\
\hline$<0.1$ & $<0.1$ & all $<0.1$ \\
\hline$<0.1$ & $<0.1$ & all $<0.1$ \\
\hline$<0.1$ & $<0.1$ & all $<0.1$ \\
\hline
\end{tabular}

In an attempt to explain much of the variation shown in the above early tests, recent tests of infiltration through disturbed urban soils were conducted in the Birmingham, AL, area by the author and UAB students. Eight categories of soils were tested, with about 15 to 20 individual tests conducted in each of eight categories (comprising a full factorial experiment). Numerous replicates were needed in each category because of the expected high variation in infiltration rates. The eight categories tested were as follows:

\begin{tabular}{clll}
\hline Category & Soil Texture & Compaction & Moisture \\
\hline 1 & Sand & Compact & Saturated \\
2 & Sand & Compact & Dry \\
3 & Sand & Non-compact & Saturated \\
4 & Sand & Non-compact & Dry \\
5 & Clay & Compact & Saturated \\
6 & Clay & Compact & Dry \\
7 & Clay & Non-compact & Saturated \\
8 & Clay & Non-compact & Dry \\
\hline
\end{tabular}

Figure 4.8 contains plots showing the interactions of moisture and compaction on infiltration for both soil texture conditions. Four general conditions were observed to be statistically unique: 
- noncompact sandy soils

- compact sandy soils

- noncompact and dry clayey soils

- all other clayey soils

\section{Clay}

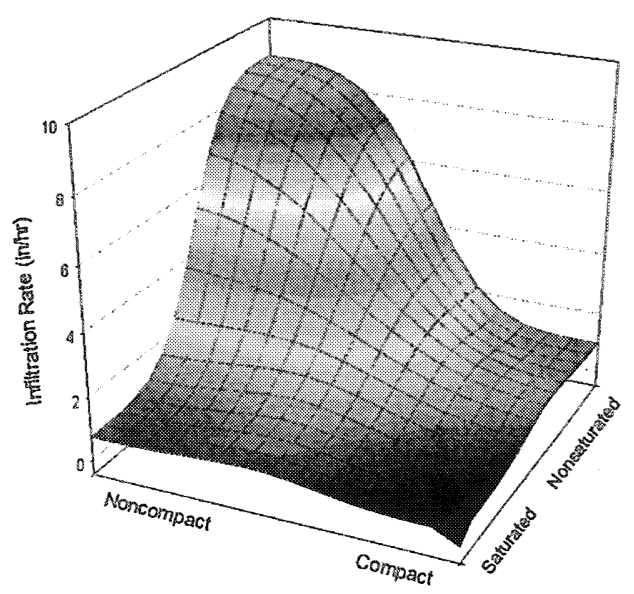

Figure 4.8a Interactions of soil moisture and compaction on infiltration rates for clayey urban soils (preliminary data by Pitt and Lantrip).

\section{Sand}

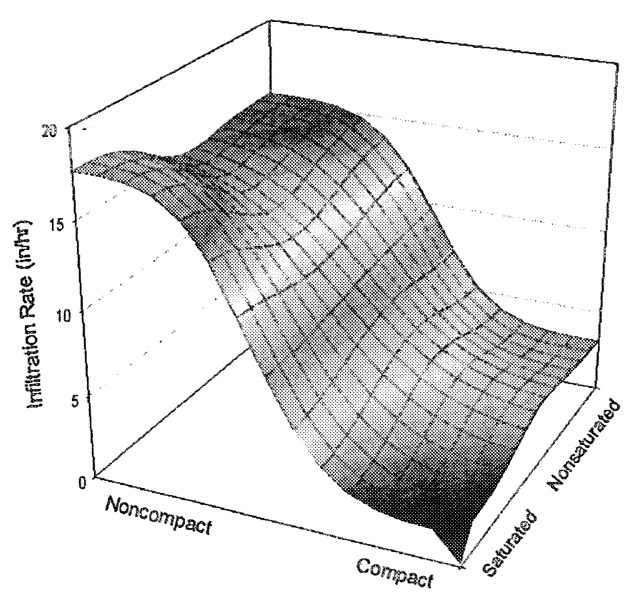

Figure 4.8b Interactions of soil moisture and compaction on infiltration rates for sandy urban soils (preliminary data by Pitt and Lantrip). 
Compaction has the greatest effect on infiltration rates in sandy soils, with little detrimental effects associated with soil moisture. Clay soils, however, are affected by both compaction and moisture. Compaction is seen to have about the same effect as moisture on these soils, with saturated and compacted clayey soils having very little effective infiltration. In most cases, the mapped soils were similar to what was measured in the field. However, significant differences were found at many of the 146 test locations. Table 4.4 shows that the 2 -hour averaged infiltration rates and their COVs in each of the four major categories were about 0.5 to 2 . Although these COVs are generally high, they are much less than if compaction was ignored. These data are being fitted to conventional infiltration models, but the high variations within each of the four main categories makes it difficult to identify legitimate patterns, implying that average infiltration rates within each event may be most suitable for predictive purposes. The remaining uncertainty can be considered using Monte Carlo components in runoff models. More detailed analyses of these data will be presented in the next volume in this series of monographs.

Very large errors in soil infiltration rates can easily be made if published soil maps and typical models are used for typically disturbed urban soils. Knowledge of compaction (which can be mapped using a cone pentrometer, or estimated based on expected activity on grassed areas) can be used to much more accurately model stormwater runoff quantity.

Table 4.4 Infiltration rates for different soil texture, moisture, and compaction conditions.

\begin{tabular}{lccc}
\hline & Number of tests & Average infiltration rate (in/hr) & COV \\
\hline noncompact sandy soils & 29 & 17 & 0.43 \\
compact sandy soils & 39 & 2.7 & 1.8 \\
noncompact and dry clayey soils & 18 & 8.8 & 1.1 \\
all other clayey soils & 60 & 0.69 & 2.1 \\
\hline
\end{tabular}

\subsubsection{General Runoff Loss Model}

As shown in the above two discussions, more rain typically infiltrates through pavement surfaces and less rain infiltrates through soils than is usually expected. This dramatically affects the predictions of relative contributions of runoff and pollutants from different source areas, and in turn, results in erroneous designs and calculations of stormwater pollutant control benefits associated with runoff control practices. The following discussion outlines the general runoff loss model used by Pitt (1987) to more accurately describe urban runoff processes over a wide range of rains. 
When rain falls on an impervious surface, much of it will flow off the surface and contribute to the total urban runoff. With the exception of infiltration, rainfall abstractions are mostly associated with the initial portions of the rain and are termed initial abstractions. Water may also infiltrate through pavement, or through cracks or seams in the pavement. For small rains, a much greater portion of the rain will be lost to these runoff loss processes than for large rains.

Paved surfaces are usually considered impervious, implying no infiltration. However, numerous researchers have long concluded that paved surfaces do indeed experience infiltration losses (such as Willeke 1966; Cedergren 1974; Falk and Niemczynowicz 1978; Pratt and Henderson 1981; Davies and Hollis 1981; and Pitt 1987).

Both small-scale and large-scale tests, described by Pitt (1987), obtained data to calibrate and verify a model for homogeneous impervious and pervious areas (similar to the plot shown in Figure 4.6). The runoff response curve departs from the $\mathrm{x}$-axis at the rainfall depth when runoff begins. This depth lag corresponds to initial runoff losses (detention storage, evaporation losses due to pavement cooling, and dirt and debris absorbing moisture for pavements). After some rain depth, infiltration into the ground (or pavement or through cracks) slows practically to nothing, and each additional increment of rainfall results in a similar increment of runoff. Between these two rain depths, infiltration losses occur. Figure 4.9 shows the model describing these infiltration losses. This figure plots cumulative variable runoff losses $(\mathrm{F}$, inches or $\mathrm{mm})$, ignoring the initial losses, versus cumulative rain ( $P$, inches or $\mathrm{mm}$ ), after runoff begins. The slope of this line is the instantaneous variable runoff loss (infiltration) occurring at a specific rain depth after runoff starts. A simple nonlinear model can be used to describe this relationship which is similar to many other infiltration models. For a constant rain intensity (i), total rain depth since the start of runoff $(P)$, equals intensity times the time since the start of runoff $(\mathrm{t})$. The general nonlinear model for this variable runoff loss $(F)$ is therefore:

$$
\mathrm{F}=\mathrm{bit}+\mathrm{a}\left(1-\mathrm{e}^{-\mathrm{git}}\right) \text { or } \mathrm{F}=\mathrm{bP}+\mathrm{a}\left(1-\mathrm{e}^{-\mathrm{gP}}\right)
$$

Three basic model parameters were used to define the model behavior, in addition to initial runoff losses and rain depth: "a", the intercept of the equilibrium loss line on the cumulative variable loss axis; " $b$ ", the rate of the variable losses after equilibrium; and "g", an exponential coefficient. If variable losses are zero at equilibrium, then " $b$ " would be zero. Because this plot does not consider initial runoff losses, the variable loss line must pass through the origin. This model reduces to the SCS model when the " $\mathrm{b}$ " is zero and " $\mathrm{a}$ " is S", and when Ia is 0.16 ( $80 \%$ of 0.2 ) of "a". This general model also reduces to the Horton equation when cumulative rain depth since the start of the event is used instead of just time since the start of rain. 


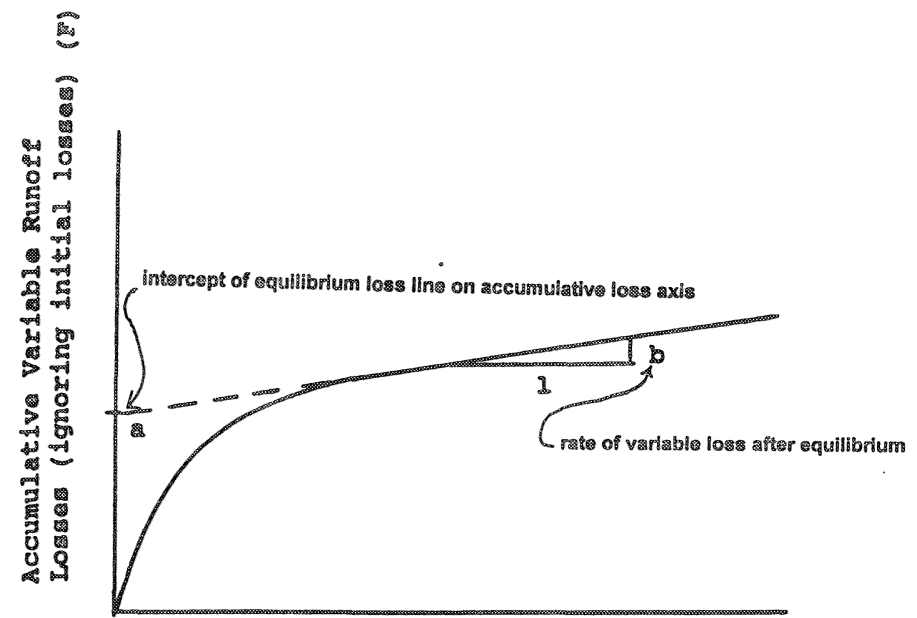

Accumulatve Rain (after initial Los:

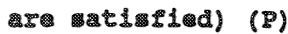

$$
\begin{aligned}
& F=b P+a\left(1-e^{-8 P}\right) \\
& \text { whore } F=\text { accumulative variable losses } \\
& g=\text { exponential coefficlent } \\
& P \approx \text { accumulatod rainfall }
\end{aligned}
$$

If $\mathrm{b}=0$, then a $=$ total losses and no steady state losses occur (equivalent to SCS model)

Nota: tme sinc runofi startsd is not a factor (as Implied by most users of Morton equation).

Figure 4.9 Cumulative variable runoff loss model for pavement (Pitt 1987).

Observed runoff data from both small- and large-scale tests were fitted to this equation to determine the values for $a, b$, and $g$ for observed $i$ and $t$ (or $P$ ), and $\mathrm{F}$. In addition, outfall runoff observations from many different heterogeneous land uses were used to verify the calibrated model (Pitt 1987).

\subsubsection{Volumetric Runoff Coefficients}

Table 4.5 is a summary of the volumetric runoff coefficients $(R v$, the ratio of runoff to rainfall volume) for different urban surfaces and rain depths from detailed source area runoff tests and through calibrating the general runoff model (Pitt 1987). Flat roofs and unpaved parking areas behave strangely similar because of similar detention storage volumes and no infiltration. Large impervious areas have the largest runoff yields because of very poor pavement underdrainage. The drainage path through the pavement base is relatively thin and very long, making it very difficult for infiltrated water to drain from the base. Street widths are much narrower than the widths of large impervious areas and the base 
water can drain much more effectively. Pitched roofs have no infiltration rates, but do experience limited initial losses associated with flash evaporation and sorption of moisture in leaves and other roof or gutter debris. After three inches (no longer a "small" rain) the runoff yields from all impervious surfaces are similar (within 10\%), but the differences can be very large for the small rains of most concern in water quality evaluations.

The impervious and roof area values are for directly connected surfaces. If runoff is allowed to drain across grass areas, then the runoff yield may significantly decrease. However, sufficient length of drainage across the pervious surface in good condition is needed. For a relatively small paved surface, short pervious drainage paths are all that are needed. If the paved area is large, or if the pervious area has clayey or compacted soils, then much longer drainage paths are needed before significant infiltration occurs.

Table 4.5 does not accurately incorporate the effects of disturbed urban soils presented earlier, but the runoff coefficients shown generally bracket the range of likely conditions expected. Some users have had good success using an intermediate value of soil Rv, half way between the clayey and sandy soil conditions shown, and only using the extreme values for more unusual cases. The four urban soil categories identified earlier better represent the conditions encountered, and appropriate coefficients are currently being developed.

The runoff coefficients and indirect connection corrections were determined from calibrating the small storm hydrology model for large urban watersheds having variable complexities in Toronto and in Milwaukee (Pitt 1987). The first calibrations were conducted for simple areas. The first area was the large parking area of a commercial shopping area. The runoff coefficients for this area were used to determine the runoff relationships from large flat roofs from another shopping area that was made of mostly paved large parking and roof areas in order to determine runoff characteristics for flat roofs. The next step was to evaluate runoff data for two high-density residential areas that had very little pervious areas and had all of the impervious areas directly connected. The street runoff was subtracted from the total area runoff observations to obtain information solely for pitched roofs. Finally, two medium-density residential areas were studied in areas that had clayey soils and all of the impervious areas were directly connected. Roof, street and other impervious area runoff information was subtracted to obtain clayey soil runoff coefficients. Similarly, a mediumdensity residential area was studied in an area having sandy soils to obtain sandy soil runoff coefficients. Finally, two medium density residential areas having unconnected impervious areas were studied to obtain correction coefficients. 
Table 4.5 Summary of volumetric runoff coefficients for urban runoff flow calculations (Pitt 1987).

Runoff coefficients for directly connected areas:

\begin{tabular}{|c|c|c|c|c|c|c|c|c|}
\hline \multicolumn{2}{|c|}{ Rain Depth } & \multirow{2}{*}{$\begin{array}{l}\text { Flat roofs* (or large } \\
\text { unpaved parking areas) }\end{array}$} & \multirow{2}{*}{$\begin{array}{l}\text { Pitched } \\
\text { roofs* }\end{array}$} & \multirow{2}{*}{$\begin{array}{l}\text { Large im- } \\
\text { pervious areas* }\end{array}$} & \multirow{2}{*}{$\begin{array}{l}\text { Small impervious } \\
\text { areas and streets }\end{array}$} & \multirow[t]{2}{*}{ Sandy soils } & \multirow{2}{*}{$\begin{array}{l}\text { Typical } \\
\text { urban soils }\end{array}$} & \multirow[t]{2}{*}{ Clayey soils } \\
\hline $\mathrm{mm}$ & inches & & & & & & & \\
\hline 1 & 0.04 & 0.00 & 0.25 & 0.93 & 0.26 & 0.00 & 0.00 & 0.00 \\
\hline 3 & 0.12 & 0.30 & 0.75 & 0.96 & 0.49 & 0.00 & 0.00 & 0.00 \\
\hline 5 & 0.20 & 0.54 & 0.85 & 0.97 & 0.55 & 0.00 & 0.05 & 0.10 \\
\hline 10 & 0.39 & 0.72 & 0.93 & 0.97 & 0.60 & 0.01 & 0.08 & 0.15 \\
\hline 20 & 0.79 & 0.83 & 0.96 & 0.97 & 0.67 & 0.02 & 0.11 & 0.20 \\
\hline 30 & 1.2 & 0.86 & 0.98 & 0.98 & 0.73 & 0.03 & 0.12 & 0.22 \\
\hline 50 & 2.0 & 0.90 & 0.99 & 0.99 & 0.84 & 0.07 & 0.17 & 0.26 \\
\hline 80 & 3.2 & 0.94 & 0.99 & 0.99 & 0.90 & 0.15 & 0.24 & 0.33 \\
\hline
\end{tabular}

"If these "impervious" areas drain for a significant length across sandy soils, the sandy soil runoff coefficients will usually be applied to these areas, however, if these areas drain across clayey soils, the runoff coefficients will be reduced, depending on the land use and rain depth, according to the following table:

Reduction factors for different rain depths $(\mathrm{mm})$ :

\begin{tabular}{lllllllllll}
\hline & 1 & 3 & 5 & 10 & 15 & 20 & 30 & 50 & 80 & 125 \\
\hline Strip commercial and shopping centers & 0.00 & 0.00 & 0.47 & 0.90 & 0.99 & 0.99 & 0.99 & 0.99 & 0.99 & 0.99 \\
Other medium to high density land uses, with alleys & 0.00 & 0.08 & 0.11 & 0.16 & 0.20 & 0.29 & 0.46 & 0.81 & 0.99 & 0.99 \\
Other medium to high density land uses, without alleys & 0.00 & 0.00 & 0.11 & 0.16 & 0.20 & 0.21 & 0.22 & 0.27 & 0.34 & 0.46 \\
\hline
\end{tabular}

If low density land uses, use clayey soil runoff coefficients. 


\subsubsection{Example Validation of General Small Storm Hydrology Model}

The final runoff coefficients were validated using additional runoff data from these same areas (that were not used in the calibration efforts) and from areas located elsewhere. Figures 4.10 through 4.13 show how well the small storm hydrology model works over a wide range of rain depths and for two very different land uses. The "Post Office" site was a commercial shopping center, the "Burbank" site was a medium density residential area. These sites were monitored as part of the EPA's NURP project in Milwaukee (Bannerman, et al. 1983). Figures 4.12 and 4.13 are for two residential sites monitored by the WI DNR in Superior, WI, and in Marquette, MI, during 1993 and 1994. These last two sites were compared to the small storm hydrology component of SLAMM with no local calibration, demonstrating the excellent fit of observed and computed flows. The model was subsequently calibrated for these two sites to enable better fits for the larger events (due to inaccurate initial estimates of soil conditions). It was originally expected that this model would not work very well for very large storms, especially in areas having appreciable pervious areas, where rain intensity was expected to have a more significant effect on infiltration than for small rains. The largest rains observed for the two Milwaukee sites were greater than 3 inches $(77 \mathrm{~mm})$, very large rains that would not be expected to commonly occur. Even these rains had runoff quantities that were well reproduced by this general runoff model.

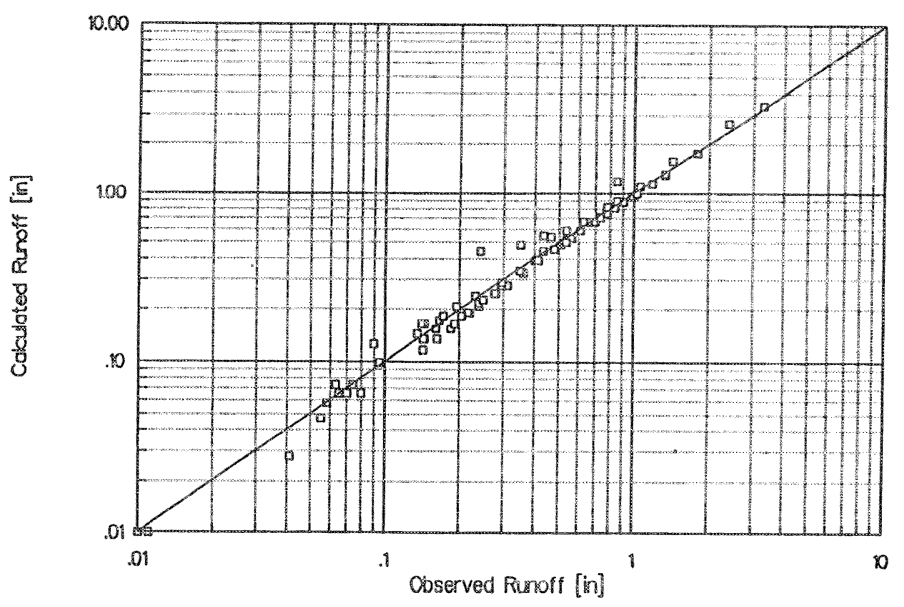

Figure 4.10 General hydrology model validation plot for Post Office commercial site (Milwaukee) (Pitt 1987). 


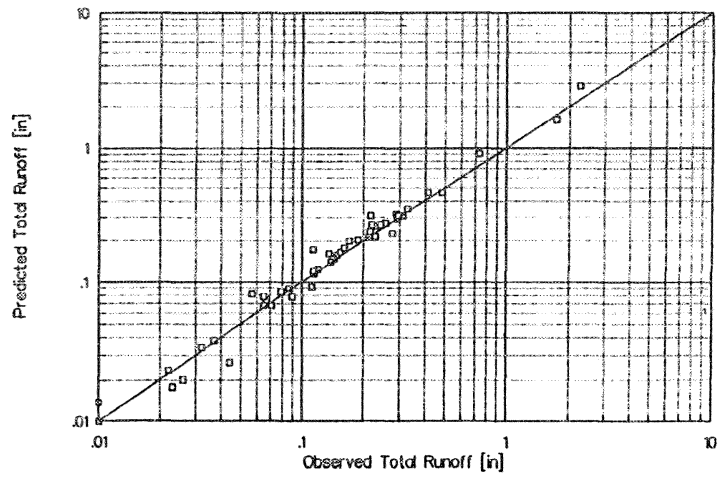

Figure 4.11 General hydrology model validation plot for Burbank residential site (Milwaukee) (Pitt 1987).

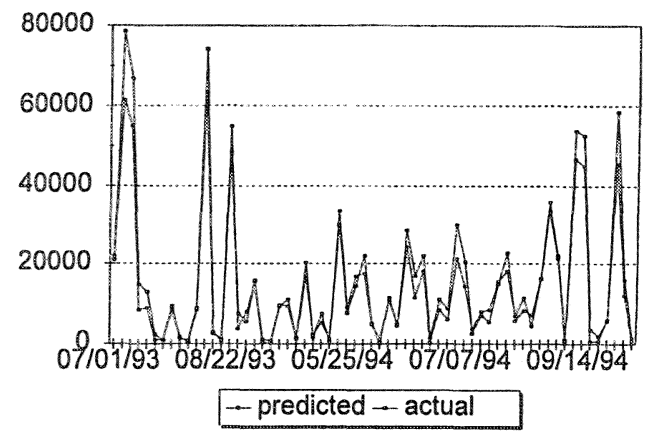

Figure 4.12 SLAMM validation plot for Superior, WI, $\mathrm{ft}^{3}$ of runoff (personal communication, Jeff Prey, WI DNR).

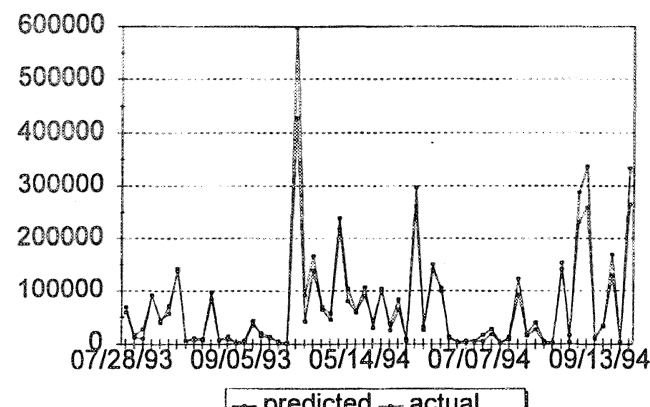

Figure 4.13 SLAMM validation plot for Marquette, $\mathrm{MI}, \mathrm{ft}^{3}$ of runoff (personal communication, Jeff Prey, WI DNR). 


\subsection{Conclusions}

Runoff volume is the most important hydraulic parameter needed for most water quality studies, while peak flow rate and time of concentration are the most important parameters for most flooding and drainage studies. Common small rains account for much more of the annual runoff volume than rare flooding events. Pitt (1987) showed that estimates of runoff volume could be made with only rain depth information. Other rain characteristics (including antecedent conditions, durations, intensities, etc.) did not substantially improve runoff volume predictions, but are likely needed for peak flow rate predictions.

The literature indicates that both initial runoff abstractions (mostly detention/storage) and continuous runoff losses (infiltration) are important for impervious surfaces. Recent work with disturbed urban soils has also shown that care must be taken when using soil maps for developed conditions. The general model successfully predicts runoff from several types of paved, roofed, and disturbed soil urban surfaces. This model was shown to accurately compute runoff volumes for a wide range of rain conditions.

This model was used to examine long-term rain conditions at many locations throughout the U.S. to indicate the significance of small and moderate sized rains in stormwater management. These smaller rains, compared to the typical "design storm" rains used for drainage system design, contribute most stormwater pollutants. Stormwater control practices must therefore effectively address these smaller storms to provide effective pollutant and flow reduction schemes.

\section{References}

Bannerman, R., K. Baun, M. Bohn, P.E. Hughes, and D.A. Graczyk. 1983. Evaluation of Urban Nonpoint Source Pollution Management in Milwaukee County, Wisconsin, Vol. I. PB 84-114164. US Environmental Protection Agency, Water Planning Division, November 1983.

Cedergren, H.R. 1974. Drainage of Highway and Airfield Pavements. John-Wiley and Sons, New York.

Davies, H. and T. Hollis. 1981. "Measurements of Rainfall-Runoff Volume Relationships and Water Balance for Roofs and Roads." Second International Conference on Urban Storm Drainage, Urbana, Illinois, June 1981.

EPA (U.S. Environmental Protection Agency). 1983. Final Report for the Nationwide Urban Runoff Program. Water Planning Division, Washington, D.C., December 1983.

Falk, J. and J. Niemczynowicz. 1978. "Characteristics of the above-ground runoff in sewered catchments." in Urban Storm Drainage. P.R. Helliwell, ed. John Wiley and Sons, New York. 
Gregory, M. and W. James. 1996. "Management of Time Series Data for Long-term Continuous Stormwater Modeling." Journal of Water Management Modeling R191-08. doi: 10.14796/JWMM.R191-08.

Heaney, J.P., W.C. Huber, M.A. Medina, Jr, M.P. Murphy, S.J. Nix, and S.M. Hasan. 1977. Nationwide Evaluation of Combined Sewer Overflows and Urban Stormwater Discharges, Volume II: Cost Assessment and Impacts. EPA-600/2-77-064b. NTIS PB-266005. 363 pgs. U.S. Environmental Protection Agency. Cincinnati, Ohio. March 1977.

Hormadka, T.V. II. 1982. Computer Methods in Urban Hydrology, Rational Methods and Unit Hydrograph Methods. Lighthouse Publications, Anaheim, California.

Huber, W.C. 1981.Urban Rainfall-Runoff-Quality Data Base: Addendum I: Statistical Analysis and Additional Data. EPA-600/2-81-238, U. S. Environmental Protection Agency, Cincinnati, Ohio.

Pitt, R. 1986."The incorporation of urban runoff controls in the Wisconsin Priority Watershed Program." In: Advanced Topics in Urban Runoff Research, (Edited by B. Urbonas and L.A. Roesner). Engineering Foundation and ASCE, New York. pp. $290-313$.

Pitt, R. 1987. Small Storm Flow and Particulate Washoff Contributions to Outfall Discharges. Ph.D. dissertation, Department of Civil and Environmental Engineer ing, the University of Wisconsin, Madison.

Pitt, R. and J. Voorhees. 1995. "Source loading and management model (SLAMM)." Seminar Publication: National Conference on Urban Runoff Management: Enhancing Urban Watershed Management at the Local, County, and State Levels. March 30 - April 2, 1993. Center for Environmental Research Information, U.S. Environmental Protection Agency. EPA/625/R-95/003. Cincinnati. Ohio. pp. 225-243. April 1995.

Pitt, R., M. Lilburn, S. Nix, S.R. Durrans, and S. Burian. 1997. Guidance Manual for Integrated Wet Weather Flow (WWF) Collection and Treatment Systems for Newly Urbanized Areas (New WWF Systems). First year project report. U.S. Environmental Protection Agency. 612 pgs. June 1997.

Pratt, C.J. and R.J. Henderson. 1981. "Overland flow and catchment characteristics." Second International Conference on Urban Storm Drainage, Urbana, Illinois, June 1981.

SCS (U.S. Soil Conservation Service). 1986. Urban Hydrology for Small Watersheds. U.S. Dept. of Agriculture Tech. Release No. 55 (revised), June 1986.

Singh, V.P. and S. Buapeng. 1977. "Effect of rainfall-excess determination on runoff computation." Water Resources Bulletin, Vol. 13, No. 3, June 1977.

Skaggs, R.W., L.E. Huggins, E.J. Monke and G.R. Foster. 1969. "Experimental evaluation of infiltration equations." Transactions of the American Society of Agricultural Engineers, pp 822-828.

Willeke, G.E. 1966. "Time in urban hydrology." Journal of the Hydraulics Division, Proceedings of the American Society of Civil Engineers, Vol.92, No. HY1, January 1966. 


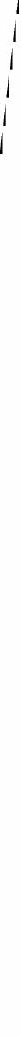

